\author{
RAFAE P. PIPREK \\ Zakład Anatomii Porównawczej im. Henryka Hoyera \\ Instytut Zoologii i Badań Biomedycznych \\ Uniwersytet Jagielloński \\ Gronostajowa 9, 30-387 Kraków \\ E-mail: rafal.piprek@uj.edu.pl
}

\title{
HISTORIA NATURALNA ŁUSEK RYB - BUDOWA, EWOLUCJA I ROZWÓJ
}

\section{WSTEP}

Jedną $z$ funkcji skóry jest ochrona przed czynnikami środowiska zewnętrznego i w zwiazku $z$ tym, w wielu liniach ewolucyjnych kręgowców wykształciły się twarde elementy wzmacniające ochronę tego największego narządu. Skóra kręgowców składa się z naskórka, będącego nabłonkiem wielowarstwowym płaskim pochodzącym $z$ ektodermy, oraz ze skóry właściwej zbudowanej $z$ tkanki łacznej pochodzenia mezodermalnego. U przedstawicieli poszczególnych grup kręgowców zarówno naskórek, jak i skóra właściwa tworzą różnorodne wytwory, zapewniajace ochronę. Łuski ryb sa wytworem skóry właściwej, ale najczęściej powstaja przy udziale naskórka. Zmineralizowane wytwory skóry w postaci łusek i pancerzy były obecne już u wczesnych kręgowców bezszczękowych i tworzyły ich szkielet skórny. Najprawdopodobniej to właśnie w skórze powstała po raz pierwszy tkanka kostna.

\section{ZARYS EWOLUCJI RYB I ICH ŁUSEK}

Najstarsze szczątki kręgowców datowane sa na ok. $520 \mathrm{mln}$ lat, co przypada na okres wczesnego kambru (SHU i współaut. 2003). Nie odnaleziono w nich śladów jakichkolwiek mineralnych wytworów ani łusek. Najwcześniejsze przejawy mineralizacji szkieletu zaobserwowano u kręgowców $z$ późnego kambru (DONOGHUE i ALDRIDGE 2001). Natomiast pierwsze elementy zmineralizowanego szkieletu skórnego, w postaci kości pokrytych zębiną i substancją (tkanką) szkliwo-podobna na szczycie, zaobserwowano w skórze przedstawicieli kopalnych, pancernych bezszczękowców (Agnatha) z grupy pteraspidomorfów (Pteraspidomorphi), które pojawiły się około $460 \mathrm{mln}$ lat temu, a więc w okresie ordowiku (DONOGHUE i SANSOM 2002). Prawdopodobnie powstanie białek wiażących wapń (białka SCPP) umożliwiło mineralizacje szkieletu u wczesnych kręgowców, co stało się wstępem do powstania tkanki kostnej i rozbudowanego szkieletu.

Popularna obecnie hipoteza zakłada, że pierwotnymi elementami szkieletu skórnego były niewielkie twory zmineralizowane, zbudowane $z$ zębiny pokrytej twarda substancja szkliwo-podobna, osadzone na kostnej płytce, posiadajace jamę w środku, struktura przypominajace zabki (REIF 1982). Struktury te, zwane odontodami, były łuskami pokrywającymi ciało niektórych paleozoicznych bezszczękowców, takich jak telodonty (Thelodonti) i anaspidy (Anaspida). Odontody miały tendencje do zrastania się i tworzenia w ten sposób większych struktur, tzw. odontokompleksów, a nawet litych płyt o złożonej strukturze. W ten sposób powstały pancerze pokrywające ciało pancernych bezszczękowców żyjacych w erze paleozoicznej, takich jak heterostraki (Heterostraci) czy osteostraki (Osteostraci). Zakładano, że pancerz pierwotnych bezszczękowców miał chronić przed rozerwaniem ciała $\mathrm{w}$ wyniku stresu osmotycznego zwierzęcia przebywającego w słodkiej wodzie (GRODZIŃSKI 1978). Obecnie wiadomo, że środowiskiem życia wspomnianych paleozoicznych bezszczękowców były głównie wody morskie, a więc to raczej ochrona 
przed drapieżnikami, takimi jak staroraki, była funkcja opisywanego pancerza.

Kostny pancerz skórny został odziedziczony przez pierwsze szczękowce (Gnathostomata), które pojawiły się we wczesnym sylurze (BURROW i TURNER 1999). Paleozoiczne ryby pancerne, zwane także tarczowcami lub rybami tarczowymi (Placodermi), jako jedne z pierwszych szczękowców posiadały silnie rozwinięte płyty kostne pokrywające przód ciała oraz mniejsze łuski pokrywające tułów i ogon. U paleozoicznych akantodów, czyli ryb fałdopłetwych (Acanthodii), występowały drobniejsze płytki kostne na głowie i łuski pokrywajace tylne odcinki ciała (BURRow i współaut. 2012). Pierwotne szczękowce dały początek dwóm współcześnie występujacym grupom ryb: chrzęstnoszkieletowym (Chondrichthyes) i kostnoszkieletowym (Osteichthyes). Przedstawiciele gromady ryb chrzęstnoszkieletowych posiadaja łuski plakoidalne o strukturze przypominajacej budowa zęby. Pierwsze ryby kostnoszkieletowe wykształciły grube, rombowe łuski ułożone w rzędy. Ryby te wcześnie podzieliły się na dwie linie ewolucyjne: gromadę ryb mięśniopłetwych (Sarcopterygii) i gromade ryb promieniopłetwych (Actinopterygii). U wczesnych ryb mięśniopłetwych, które dały poczatek rybom trzonopłetwym (Crossopterygii), rybom dwudysznym (Dipnoi) i czworonogom (Tetrapoda), powstały łuski kosmoidalne, zawierajace kosminę, czyli specyficzny układ kanałów i porów (SchUlTZe 2016). Następnie na drodze ewolucji łuski te ulegały redukcji do cienkich elastycznych płytek, zwanych łuskami elastycznymi lub elasmoidalnymi. U wczesnych ryb promieniopłetwych występowały łuski ganoidalne (ganoidowe), pokryte gruba warstwa szkliwa (ganoina). Łuski ganoidalne również ulegały stopniowej redukcji, co jest widoczne w różnorodności struktury łusek przedstawicieli ryb promieniopłetwych takich jak: wielopłetwiec (Polypterus), jesiotr (Acipenser), niszczuka (Lepisosteus), miękławka (Amia) i w końcu ryby doskonałokostne (Teleostei) (SCHULTZE 2016). Teleostei stanowia nieomalże połowę współcześnie żyjących kręgowców i posiadaja łuski zredukowane do cienkich łusek elastycznych, czyli elasmoidalnych. Redukcja warstw tworzacych grube, pierwotne łuski do cienkich lusek elastycznych wiazała się $z$ obniżeniem ciężaru ciała i zwiększeniem jego ruchomości i następowała niezależnie w kilku liniach ewolucyjnych. W niektórych liniach ewolucyjnych Teleostei doszło do wtórnego wytworzenia grubych kostnych tworów; np. powstały różnorodne skostnienia $\mathrm{w}$ postaci zabków skórnych u przedstawicieli kilku rodzin tej grupy, kostnych tarczek u pancernych sumików i kostnych płyt u ciernikowatych. Pochodna szkieletu skórnego sa także niektóre kości czaszki (dermatocranium) i kostne promienie płetw (lepidotrichia) (SIRE i HUYSSEUNE 2003). Skostnienia w skórze czworonogów odziedziczone po rybich przodkach, jak i powstałe de novo zwane sa osteodermami.

\section{ELEMENTY SZKIELETU SKÓRNEGO I JEGO TKANKI}

Wszystkie tkanki tworzace łuski ryb sa $\mathrm{w}$ mniejszym lub większym stopniu zmineralizowane. U wczesnych kręgowców powstały geny SCPP (ang. secreting calcium-binding phosphoproteins) kodujące białka wiążace sole wapnia $\mathrm{w}$ przestrzeni międzykomórkowej. Umożliwiło to rozwój zmineralizowanych tkanek i szkieletu (SIRE i KAWASAKI 2012). Kręgowce zaczęły gromadzić fosforan wapnia $\mathrm{w}$ postaci hydroksyapatytu [mineral o wzorze sumarycznym $\mathrm{Ca}_{10}\left(\mathrm{PO}_{4}\right)_{6}(\mathrm{OH})_{2}$ ], który jest sola słabiej rozpuszczalna, a przez to stabilniejsza od węglanu wapnia powszechnego w twardych tkankach bezkręgowców. To właśnie fosforan wapnia $\mathrm{w}$ postaci hydroksyapatytu usztywnia tkanke kostna, zębinę, szkliwo i substancje szkliwo-podobne kręgowców.

Grube, pierwotne łuski i pancerze zbudowane były $z$ trzech warstw. Zaczynajac od najgłębiej położonej warstwy obecna była: kość, zębina (dentyna) i silnie zmineralizowana warstwa powierzchniowa. $\mathrm{Na}$ drodze ewolucji warstwy te ulegały przemianom i niektóre $z$ nich zanikały.

\section{TKANKA KOSTNA}

Pierwsza w historii kość powstała właśnie $\mathrm{w}$ skórze właściwej tworzac łuski lub lite pancerze. Kość ta nazwana została aspidyną, czyli kością bezkomórkowa. Aspidyna, tak jak kość komórkowa, organizowała się w różnorodny sposób, tworząc kość gąbczasta (zwaskularyzowaną, zwana także spongina) lub zbita, która mogła występować w postaci splotowatej ( $z$ nieregularnie ułożonymi grubymi włóknami kolagenu) lub lamelarnej (blaszkowatej, zbudowanej $\mathrm{z}$ warstw), mogła także posiadać osteony (DONOGHUE i współaut. 2006). Kość ułożona w warstwy, leżąca w głębszych warstwach grubych, pierwotnych łusek zwana jest izopedyna. Tworzy ona także płytki $i$ pancerze Teleostei. U późniejszych bezszczękowców, takich jak dewońskie osteostraki (Osteostraci), pojawiła się kość komórkowa i została ona po nich oddziedziczona przez szczękowce.

Cement jest tkanka kostno-podobna, która w odróżnieniu od kości nie zawiera naczyń krwionośnych ani nerwów, może być komórkowa lub bezkomórkowa. Zakotwicza zęby ssaków i krokodyli w zębodołach. Na- 
tomiast tkanka cemento-podobna jest obecna u niektórych ryb w płytce zakotwiczajacej łuskę w skórze (OSBORN 1981).

Pomimo pewnej różnorodności struktury kości, w każdym przypadku substancja międzykomórkowa tkanki kostnej zawiera kolagen typu I i V, proteoglikany i hydroksyapatyt oraz szereg specyficznych białek jak osteokalcyna, osteoponina i osteonektyna. Poziom wysycenia tkanki kostnej substancja mineralną, a więc jej mineralizacja, osiaga $65-70 \%$.

\section{ZĘBINA (DENTYNA)}

Zębina (dentyna, ang. dentin) jest tkanka bogata w kolagen i silniej zmineralizowana niż kość (ok. 75\% substancji mineralnych), produkowana przez odontoblasty (SIRE i KAWASAKI 2012). Odontoblasty pochodza w rozwoju $z$ komórek grzebieni nerwowych, różnicuja się w obrębie tkanki mezenchymalnej skóry właściwej, układają się w warstwę komórek pod nabłonkiem skóry i zaczynaja wydzielać substancję międzykomórkową zawierajaca liczne włókna kolagenu typu I i proteoglikany. Początkowo taki wytwór odontoblastów jest niezmineralizowany (predentyna), a następnie, dzięki ekspresji białek takich jak DMP1 i DSPP (grupa białek SCPP), gromadzi fosforan wapnia i tym samym ulega mineralizacji, tworzac zębinę (SIRE i KAWASAKI 2012). Zębina wykazuje pewną różnorodność wśród kręgowców, zwłaszcza dotycząca rozmieszczenia kanalików i organizacji komórkowej. U większość kręgowców występuje tzw. zębina właściwa (ortodentyna) (ØRVIG 1967). To ona tworzy ludzkie zęby. Była obecna już u heterostraków będacych przedstawicielami pancernych bezszczękowców $z$ paleozoiku. Ortodentyna jest tworem bezkomórkowym, niezawierajacym naczyń krwionośnych, ale poprzebijanym równoległymi kanalikami zawierajacymi wypustki odontoblastów (SIRE i KAWASAKI 2012). Metdentyna zawiera mniej kanalików w porównaniu $z$ ortodentyną. U niektórych ryb kopalnych występowała tkanka zębino-podobna zwana osteodentyną. Była ona podobna do kości dzięki obecności komórek i naczyń krwionośnych w jej obrębie. Jej pierwszy rodzaj, mezodentyna, występował u paleozoicznych, pancernych bezszczękowców - osteostraków (Osteostraci) oraz u paleozoicznych ryb fałdopłetwych (Acanthodii). Wewnattrz mezodentyny występowała sieć kanalików zawierających wypustki osteoblastów rozchodzace się w różnych kierunkach. Drugi rodzaj osteodentyny, semidentyna, występował u paleozoicznych ryb pancernych (Placodermi) i charakteryzował się także obecnościa odontoblastów w jej wnętrzu, ale komórki te były spolaryzowane, a ich wypustki przebiegały w jednym kierunku w sposób uporządkowany. Pozostałe rodzaje zębiny występuja w zębach różnych grup kręgowców. Wazodentyna nie posiada kanalików dla wypustek odontoblastów, ale zawiera naczynia krwionośne i występuje w zębach niektórych ryb Teleostei i niektórych gryzoni. Bezkomórkowa i bezkanalikowa lamelina (ang. lamellin) jest zębina niektórych heterostraków i wymarłych ryb chrzęstnoszkieletowych. Pofałdowana plicydentyna (ang. plicidentin) występowała w zębach pierwszych czworonogów, a obecnie występuje u niektórych współczesnych jaszczurek, takich jak warany. Tubulodentyna (ang. tubulodentin), zbudowana $z$ długich heksagonalnych kanalików wypełnionych miazga, tworzy stale rosnace i pozbawione szkliwa zęby mrówników (ssaki $z$ rzędu rurkozębnych - Tubulidentata). Specyficzna zębina, zawierajacca wewnątrz komórki, tworzy zęby ryby miękławki (Amia calva) (SIRE i KAWASAKI 2012).

W łuskach większości ryb kostnoszkieletowych, zarówno mięśniopłetwych, jak i promieniopłetwych, znajduje się blaszkowata tkanka przypominajaca struktura sklejke, tzw. elasmodyna, która prawdopodobnie jest specyficzna forma lamellarnej zębiny. Kolejne warstwy elasmodyny zbudowane sa $z$ kolagenu i moga być w różnym stopniu zmineralizowane (SIRE i AKRIMENKO 2004). Silnie zmineralizowana elasmodyna wystepuje $u$ wielopłetwca Polypterus, słabo - u Teleostei, a niezmineralizowana u latimerii (Latimeria). Elasmodyna stanowi większa część łuski elastycznej i przez długi czas była uważana za homolog izopedyny. W podręcznikach można znaleźć informację, że łuska elastyczna jest zbudowana właśnie $z$ tkanki kostnej zwanej izopedyną (GRODZIŃSKI 1978). Obecnie podobieństwo izopedyny (blaszkowata kość) i elasmodyny (blaszkowata zębina) uznawane jest za konwergencję, a elasmodyna uchodzi za pochodna zębiny (SIRE i HUYSSEUNE 2003, SIRE i współaut. 2009). Elasmodyna okazała się korzystnym komponentem łuski, gdyż zapewnia giętkość, lekkość i szybki wzrost przez odkładanie kolejnych warstw, widocznych na powierzchni łuski jako pierścienie przyrostu.

\section{TKANKA WARSTWY POWIERZCHNIOWEJ - SZKLIWO I SUBSTANCJA SZKLIWO-PODOBNA}

Na szczycie wielu typów łusek znajduje się warstwa powierzchniowa (ang. capping tissue), która jest najsilniej zmineralizowana (do 96\% składników mineralnych) i przez to najtwardsza $z$ tkanek. Tkanka ta jest bezkomórkowa (lub ewentualnie zawiera niewiele komórek), nieunaczyniona i nie zawiera kolagenu (lub zawiera go niewiele), gdyż zostaje on wyeliminowany podczas tworzenia 
tkanki, by ustapić miejsce licznym krysztalom hydroksyapatytu (SIRE i KAWASAKI 2012).

Dwiema podstawowymi tkankami powierzchniowymi łusek i zębów kręgowców sa szkliwo (enamel) i tkanka (substancja) szkliwo-podobna (enameloid). Szkliwem nazywa się najtwardsza tkankę ciała kręgowców, produkowana przez komórki pochodzace $z$ nabłonka (ameloblasty). Natomiast substancja szkliwo-podobna nazywa się twarda, podobną do szkliwa tkankę pochodzaca $z$ zębiny, a więc produkowana przez odontoblasty.

Prawdopodobnie pierwsza tkanką powierzchniowa był enameloid pokrywajacy łuski paleozoicznych bezszczękowców (SIRE i KAWASAKI 2012). Wśród współczesnych kręgowców, enameloid, zwany czasem także adameloidem, a dawniej witrodentyna, pokrywa łuski plakoidalne i zęby ryb chrzęstnoszkieletowych. Enameloid pokrywa także ząbki skórne występujące u niektórych ryb Teleostei, a także zęby $\mathrm{w}$ jamie gębowej Teleostei $\mathrm{i}$ innych ryb promieniopletwych oraz larw płazów ogoniastych (Urodela) (DAVIT-BÉAL i współaut. 2007). Poczatkowo uważano, że enamel różni się od enameloidu powstawaniem w rozwoju. Enameloid produkowany jest, tak jak zębina, przez odontoblasty, a więc ma pochodzenie mezenchymalne, czyli łacznotkankowe, i pochodzi ze skóry właściwej, podczas gdy szkliwo tworzone jest przez ameloblasty pochodzace $z$ nabłonka, a więc ma pochodzenie ekto- lub endodermalne. Obecnie uznaje się jednak, że enameloid powstaje dzięki aktywności wydzielniczej odontoblastów, ale przy współudziale ameloblastów (DAVIT-BÉAL i współaut. 2007). $\mathrm{W}$ przypadku tworzenia enameloidu, odontoblasty najpierw syntetyzuja substancję międzykomórkową o luźnej sieci kolagenu, przypominająca predentynę, która następnie jest rozpuszczana przez proteazy, by mogła zajść silna mineralizacja. Następnie pod taka warstwa enameloidu, odontoblasty produkuja zębinę, która ma niższy stopień mineralizacji niż enameloid.

Szkliwo jest synapomorfia, a więc cecha wspólna ryb kostnoszkieletowych (Osteichthyes) (Schultze 2016). Powstało u wczesnych Osteichthyes i zostało odziedziczone przez ich potomków takich jak czworonogi (Tetrapoda). Szkliwo jest syntetyzowane jedynie przez ameloblasty, które są przekształconymi komórkami nabłonkowymi, a więc szkliwo jest wytworem nabłonka i ma pochodzenie endodermalne lub endodermalne w jamie gębowej. Ameloblasty tworza macierz bogata $\mathrm{w}$ białka odpowiedzialne za silna mineralizację, takie jak amelogenina, enameloina, ameloblastyna i tuftelina (NANCI 2003). Enzym MMP20 (enamelizyna) wydzielany przez ameloblasty rozkłada resztki kolagenu, by stworzyć przestrzeń dla wysycenia hydroksyapatytem. Hydroksyapatyt w szkliwie może być wysoce uporządkowany $\mathrm{w}$ postaci pryzmatów, jak to ma miejsce w zębach ssaków lub pryzmaty szkliwa moga nie występować, jak u pozostałych kręgowców. Enameloid nigdy nie osiaga tak wysokiego uprządkowania substancji mineralnej, co jest wynikiem sporej zawartości włókien kolagenu. Ponadto, enameloid wykazuje ciagłość z zębiną, podczas gdy szkliwo pozostaje wyraźnie oddzielone od zębiny. Pokazuje to podobieństwo enameloidu i zębiny oraz odrębność szkliwa. Jednak enameloid i szkliwo sa podobne w swojej funkcji, położeniu na szczycie łuski lub zęba oraz wysokiej twardości wynikającej $z$ silnej mineralizacji. Wyjątkowa sytuacja ma miejsce u larw płazów ogoniastych (Urodela), u których odontoblasty najpierw produkuja enameloid, a następnie zębinę pod nim (DAVIT-BÉAL i współaut. 2007). Podczas metamorfozy, ameloblasty zaczynają deponować szkliwo na powierzchni zębów. Tak więc, zęby larw Urodela sa pokryte substancja szkliwo-podobna, a zęby tych płazów po metamorfozie szkliwem. Sytuacja ta nie ma miejsca u płazów bezogonowych, gdyż ich larwy posiadaja wyjątkowe zęby rogowe, a zęby pokryte szkliwem wyrastaja de novo podczas metamorfozy.

$\mathrm{U}$ ryb mięśniopłetwych (Sarcopterygii) występuje jednowarstwowe szkliwo prawdziwe (ang. true enamel), które zostało odziedziczone przez czworonogi. U wczesnych ryb promieniopłetwych (Actinopterygii) łuski pokryte były specyficznym, zazwyczaj wielowarstwowym, szkliwem zwanym ganoina. Ganoina produkowana jest przez ameloblasty (pochodzenie ektodermalne), nie zawiera komórek ani kolagenu, zawiera amelogeninę i przez tak duże podobieństwo do enamelu, jest uznawana za homolog szkliwa prawdziwego (QU i współaut. 2015). Ganoina pokryta jest nabłonkiem, w przeciwieństwie do zębów, w których szkliwo nie jest po wyrżnięciu niczym pokryte.

Przykładem tkanki szkliwo-podobnej jest także akrodyna (ang. acrodine), która jako rodzaj silnie zmineralizowanej zębiny pokrywa zęby wielu gatunków ryb Teleostei (FRIEDMAN i BRAZEAU 2010). Kolejnym przykładem tkanki powierzchniowej jest hialoina (ang. hyaloine). Jest to słabo poznana, bezkomórkowa, silnie zmineralizowana tkanka, pozbawiona kolagenu, pokrywajaca tarczki kostne u pancernych sumików (kirysy, kiryski i zbrojniki) (SIRE 1993). Ostatnim przykładem tkanki powierzchniowej jest warstwa graniczna (ang. limiting layer) pokrywajaca tylny brzeg łuski elastycznej Teleostei (SIRE i HUYSSEUNE 2003). Tkanka ta, wcześniej zwana hialodentyna, jest silnie zmineralizowana, 
nie zawiera kolagenu i tworzy się tuż pod nabłonkiem, ale nie wiadomo $z$ której tkanki pochodzi i czy jest odpowiednikiem zębiny czy szkliwa.

\section{PRZEGLAD BUDOWY ŁUSEK W POSZCZEGÓLNYCH GRUPACH}

\section{PALEOZOICZNE BEZSZCZEKOWCE PANCERNE Z OKRESU ORDOWIKU, SYLURU I DEWONU}

U telodontów (Thelodonti), jednych $z$ najwcześniejszych paleozoicznych bezszczękowców, łuski zbudowane były $z$ korony zębinowej (ortodentyna lub mezodentyna) osadzonej na kostnej płytce, zbudowanej $z$ aspidyny (Ryc. 1A) (SANSOM i współaut. 1996). Zębina $z$ zewnatrz pokryta była enameloidem. Górna część łuski wystawała ponad powierzchnię ciała i tworzyła ząbek skierowany do tyłu ciała. U pteraspidomorfów (Pteraspidomorphi), takich jak heterostraki (Heterostraci), wystepował pancerz pokrywajacy przód ciała, zbudowany $z$ grubej warstwy aspidyny pokrytej ząbkami zębinowymi (Ryc. 1B) (DONOGHUE i współaut. 2006). Dolna część pancerza utworzona była przez kość lamellarna, na której znajdowała się kość gąbczasta o strukturze plastra miodu. $\mathrm{Na}$ wierzchu pancerza występowały guzki zbudowane $z$ zębiny (ortodentyna) pokryte enameloidem. Prawdopodobnie tak skomplikowana struktura łuski i pancerza jest pierwotna i później ulegała modyfikacjom na drodze ewolucji, na przykład redukcji. U anaspidów (Anaspida) widoczna jest $\mathrm{znacz}-$ na redukcja szkieletu skórnego. Brak u nich było zmineralizowanego szkieletu skórnego lub występował w postaci drobnych łusek zbudowanych $z$ blaszkowatej i bezkomórko-

\section{A}

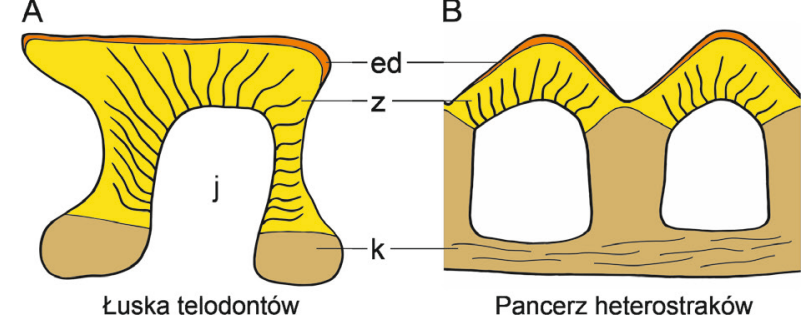

Ryc. 1. Łuska i pancerz paleozoicznych bezszczękowców. A. Łuska paleozoicznych telodontów ma postać ząbka zbudowanego z zębiny (z), pokrytego enameloidem (ed), czyli substancja szkliwo-podobną, osadzonego na kostnej płytce $(\mathrm{k})$. Wewnątrz łuski znajduje się jama (j). B. Pancerz paleozoicznych heterostraków zbudowany jest $z$ płytki kostnej (k) pokrytej zębina (z), a na jego szczycie znajduje się enameloid (ed). Pancerz ma budowę plastra miodu i posiada wewnattrz przestrzenie. wej aspidyny (JANVIER i ARSENAULT 2007). Galeaspidy (Galeaspida) to kolejne bezszczękowce, u których doszło do zaniku zębiny i enameloidu, a bezkomórkowa kość (aspidyna) była jedynym elementem pancerza (JANVIER i współaut. 1993).

U osteostraków (Osteostraci), będących bardziej zaawansowanymi pancernymi bezszczękowcami, uznawanymi za grupę siostrzaną szczękowców, pancerz złożony był $z$ płytki zbudowanej $z$ unaczynionej, blaszkowatej i komórkowej kości (pierwsza udokumentowana komórkowa kość kręgowców), na której znajdowała się warstwa elasmodyny (warstwy kolagenu), na niej warstwa zębiny (ortodentyna lub mezodentyna), a na szczycie prawdopodobnie obecny był enameloid (DonOGHuE i współaut. 2006).

\section{SZCZEKOWCE}

U ryb pancernych (tarczowce) (Placodermi), jednych $z$ pierwszych przedstawicieli szczękowców, żyjących w paleozoiku (okres syluru i dewonu), występował silnie rozwinięty pancerz, który utworzony był przez płyty komórkowej kości pokrytej ząbkami zbudowanymi $z$ zębiny (semidentyna) (DENISON 1978, Donoghue i współaut. 2006). U akantod, czyli ryb fałdopłetwych (Acanthodii), łuski zbudowane były $z$ kostnej płytki podstawnej (zazwyczaj kość bezkomórkowa), pokrytej wieloma warstwami zębiny (ortodentyna lub mezodentyna) (KARATAJUTÉ-TALIMAA i SMITH 2003). Każda $z$ warstw zębiny była tworzona przez kolejne pokolenie odontoblastów, więc zębina rosła okresowo. Zębina nie była pokryta tkanka powierzchniowa, jednak niektórzy wskazywali, że na powierzchni łusek fałdopłetwych obecne było warstwowe szkliwo przypominające ganoinę.

\section{ŁUSKI RYB CHRZESTNOSZKIELETOWYCH (CHONDRICHTHYES) - ŁUSKI PLAKOIDALNE}

Łuski plakoidalne występuja u ryb chrzęstnoszkieletowych (Chondrichthyes), a ich cechą charakterystyczna jest obecność zębinowego ząbka (Ryc. 2A, B). Ząbek łuski wystaje ponad powierzchnię naskórka i jest skierowany do tyłu. Funkcją takich struktur jest generowanie drobnych wirów wody wokół ryby, zmniejszających tarcie podczas pływania. Ząbek łuski plakoidalnej zbudowany jest $z$ zębiny (zazwyczaj ortodentyna, a $\mathrm{u}$ niektórych gatunków lamelina). Ząbek jest pokryty enameloidem, zwanym tu także adameloidem, a dawniej witrodentyna (GRODZIŃSKI 1978, MIYAKE i współaut. 1999, SIRE i HuYsSEUNE 2003). Ząbek w środku ma jamę wypełniona tkanka łaczna i jest osadzony na kostnej płytce podstawnej. Kilka ząbków może być położonych na jednej płytce kostnej, tworzac odontokompleksy. Na obrzeżach 


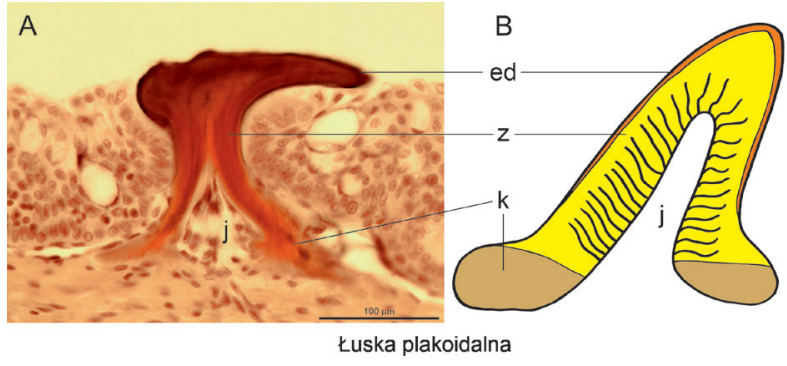

Ryc. 2. Łuska plakoidalna ryb chrzęstnoszkieletowych (Chondrichthyes). A. Mikrofotografia przekroju poprzecznego łuski plakoidalnej rekinka psiego (Scyliorhinus canicula). B. Schemat łuski plakoidalnej. Łuska ma postać ząbka zbudowanego $z$ zębiny $(z)$ pokrytej enameloidem (ed). Ząbek osadzony jest na płytce kostnej (k) i zawiera wewnattrz jamę (j).

jamy gębowej łuski plakoidalne przekształciły się w zęby. W dodatku budowa łuski plakoidalnej bardzo przypomina budowę zęba. Dlatego łuski te i zeby uznano za twory homologiczne.

\section{ŁUSKI RYB KOSTNOSZKIELETOWYCH (OSTEICHTHYES) - ŁUSKI GANOIDALNE, ELASTYCZNE I KOSMOIDALNE}

U pierwszych ryb kostnoszkieletowych (Osteichthyes), żyjacych we wczesnym dewonie, obecne były łuski grube, rombowe (SCHULTZE 2016). Z grupy tych wczesnych ryb kostnoszkieletowych wyodrębniły się dwie gromady: ryby promieniopłetwe (Actinopterygii) i mięśniopłetwe (Sarcopterygii). U wczesnych promieniopłetwych obecne były grube łuski ganoidalne pokryte ganoina (MÄRSS 2001). Natomiast u wczesnych mieśniopłetwych występowały grube łuski kosmoidalne zawierajace kosmine (ZHU i Yu 2002). Łuski tych typów ulegały redukcji w toku ewolucji. Wśród współczesnych ryb kosmina już nie występuje, a ganoina jest obecne jedynie u Polypterus i Lepisosteus.

\section{ŁUSKI GANOIDALNE}

Łuski ganoidalne pojawiły się w dewonie $\mathrm{u}$ wczesnych ryb promieniopłetwych, takich jak prawieczkowce (Paleonisciformes) (SCHUlTZE 2016). Łuski te posiadały wiele warstw szkliwa (ganoina) pokrywajacego zębinę (ortodentyna) położona na płytce zbudowanej z izopedyny (blaszkowata, komórkowa tkanka kostna). U pierwszych, sylurskich prawieczkowców (np. Androlepis żyjący ok. $420 \mathrm{mln}$ lat temu) początkowo na kości położone było kilka naprzemiennie ułożonych warstw zębiny i ganoiny. U późniejszych, dewońskich prawieczkowców (np. Dialipina żyjacca ok. $370 \mathrm{mln}$ lat temu) na jednej warstwie zębiny znajdowało się wiele warstw ganoiny.

Do współczesnych ryb kostnoszkieletowych należy kilka linii ewolucyjnych, takich jak: rzad wielopłetwcokształtnych (Polypteriformes), jesiotrokształtnych (Acipenseriformes), niszczukokształtnych (Lepisosteiformes), amiokształtych (Amiiformes), które stanowia odrębne stare linie ewolucyjne, i których przedstawiciele maja wiele cech ewolucyjnie prymitywnych, oraz około 40 rzędów ryb o zaawansowanych cechach ewolucyjnych, łaczonych w grupę ryb doskonałokostnych (Teleostei). Łuski wielopłetwcokształtnych (Polypteriformes), do których obecnie należą jedynie dwa afrykańskie rodzaje: wielopłetwiec (Polypterus) i trzcinnik (Erpetoichthys), najbardziej przypominaja pierwotne łuski ganoidalne (Ryc. 3A) (SIRE i współaut. 1987). Na warstwie izopedyny znajduje się zębina (ortodentyna), a na niej warstwa ganoiny. W zębinie znajduje się system kanałów, które prawdopodobnie odpowiadaja za odżywianie tej tkanki. Dodatkowo, łuska w tej grupie wyróżnia się obecnością elasmodyny (wyjątkowa postać blaszkowatej zębiny złożona $z$ warstw kolagenu) pomiędzy izopedyną a zębina (SIRE i współaut. 2009).

$\mathrm{U}$ niszczukokształtych, które obecnie reprezentowane sa jedynie przez północnoamerykańskie niszczuki (Lepisosteus), łuski wyróżniają się brakiem zębiny i elasmodyny, a więc na izopedynie bezpośrednio położona jest ganoina (Ryc. 3B). Redukcji uległa tu środkowa część łuski (SIRE i współaut. 2009).

W łuskach jesiotrów i blisko $z$ nimi spokrewnionego wiosłonosa amerykańskiego (Polyodon spathula) pozostały jedynie płytki kostne zbudowane $z$ izopedyny, przybierajace postać tarczek kostnych (SCHULTZE 2016). Redukcji uległy więc tutaj górne warstwy łuski.

\section{ŁUSKI ELASTYCZNE (INACZEJ ELASMOIDALNE)}

W kilku liniach ewolucyjnych łuski uległy redukcji do cienkich, lekkich i giętkich, niekrępujących ruchów ciała, łusek elastycznych, zwanych także elasmoidalnymi (Ryc. 3C). Łuski takie zachodza na siebie dachówkowato i sa położone w skórze właściwej, a więc pod naskórkiem. Łuski elastyczne występuja u amii i ryb doskonałokostynych (Teleostei), latimerii, ryb dwudysznych (Dipnoi) oraz u płazów beznogich (Apoda) (SchulTzE 2016). Łuski elastyczne Teleostei $i$ amii powstały $z$ łusek ganoidalnych, a latimerii i Dipnoi $z$ łusek kosmoidalnych. Łuska elastyczna amii i Teleostei, zbudowana $z$ elamodyny, jest uważana za formę pedo- 

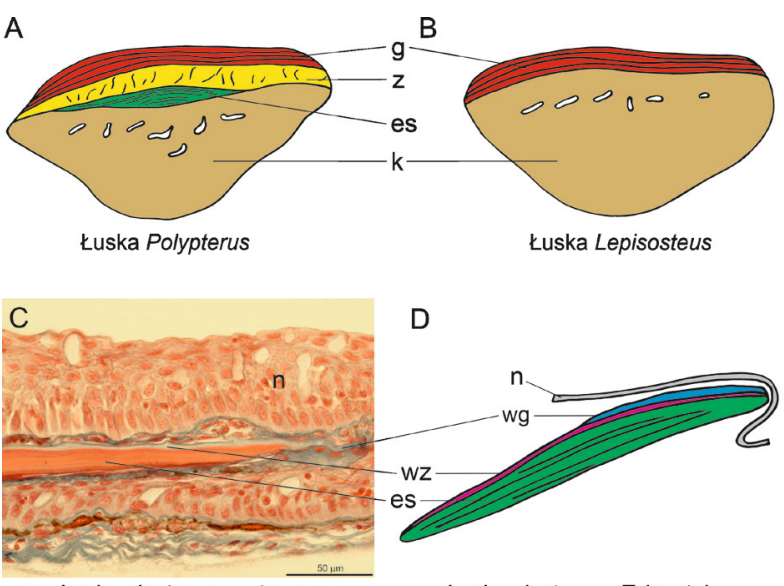

Łuska elastyczna pstrąga

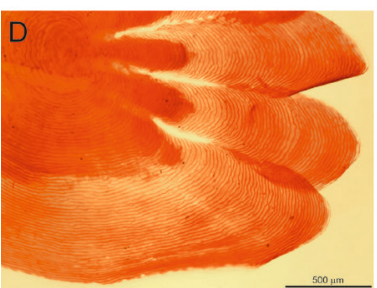

Łuska cykloidalna lipienia

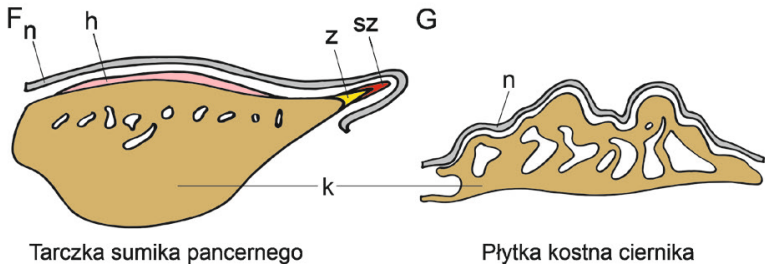

Tarczka sumika pancernego

Płytka kostna ciernika

Ryc. 3. Łuski ryb kostnoszkieletowych (Osteichthyes). A. Łuska ganoidalna Polypterus (przekrój poprzeczny) pokryta jest wielowarstwowym szkliwem - ganoina (g), pod którym znajduje się zębina (z). Dolną część łuski stanowi tkanka kostna (k). Pomiędzy tkanką kostną a zębiną nagromadzone sa warstwy kolagenu zwane elasmodyna (es). B. Łuska ganoidalna Lepisosteus ma postać płytki kostnej (k) pokrytej jedynie ganoina (g). C. Mikrofotografia przekroju poprzecznego przez łuskę elastyczną pstraga tęczowego (Oncorhynchus mykiss). D. Schemat budowy łuski elastycznej Teleostei. Łuska ta zbudowana jest $z$ warstw elasmodyny (es) pokrytej cienką warstwą zewnętrzna (wz), a na jej powierzchni od strony naskórka (n) znajduje się warstwa graniczna (wg). E. Mikrofotografia łuski cykloidalnej lipienia (Thymallus thymallus). Widoczne liczne pierścienie (circuli) na powierzchni łuski. F. Mikrofotografia łuski ktenoidalnej okonia (Perca fluviatilis). Na tylnym brzegu łuski widoczny grzebień (kt, cten) zbudowany z licznych wyrostków. F. Tarczka skórna sumików pancernych zbudowana jest $z$ tkanki kostnej $(\mathrm{k})$ pokrytej warstwa hialoiny (h). Na tylnym końcu tarczki znajduje się ząbek zbudowany z zębiny (z) pokrytej szkliwem (sz). G. Skórna płytka kostna ciernika zbudowana jest wyłącznie $z$ tkanki kostnej $(\mathrm{k})$. morficzna powstała $z$ łuski ganoidalnej jaka wystepuje u Polypterus (SIRE i HuYsSEUne 2003).

U wczesnych amiokształtnych, znanych $\mathrm{Z}$ okresu triasu (ok. $250 \mathrm{mln}$ lat temu), łuski były jeszcze ganoidalne. Jedynym współczesnym przedstawicielem tego rzęu jest północnoamerykańska amia, czyli miękławka (Amia), o zredukowanych, cienkich łuskach elastycznych (MEUNIER 1981).

U Teleostei łuska elastyczna składa się z trzech części: (i) płytka podstawna (ang. basal plate) zbudowana $z$ elasmodyny, która powoli ulega mineralizacji, na jej powierzchni (ii) cienka, ornamentowana warstwa zewnętrzna (ang. external layer), przypominajacca dobrze zmineralizowana zębinę, a na tylnym krańcu łuski (iii) silnie zmineralizowana warstwa graniczna (ang. limiting layer), przypominajacca substancję szkliwo-podobna (Ryc. 3C, D) (MEUNIER 1981, SIRE i współaut. 2009). W warstwie granicznej nie ma kolagenu, a jedynie materiał włóknisty i ziarnisty silnie zmineralizowany. Być może warstwa ta pochodzi $z$ ganoiny. Łuski elastyczne miękławki i Teleostei powstały zapewne niezależnie od siebie i obecnie sa uznawane za paralelizm, a więc wynik niezależnej, równoległej ewolucji.

Zębina, w przeciwieństwie do szkliwa, może narastać w czasie życia zwierzęcia. W szybszym tempie narasta w okresie letnim, gdy temperatura jest wyższa i dostępna jest większa ilość pokarmu. W ten sposób powstaja pasma przyrostu, po których możliwe jest określenie wieku ryby. Większość ryb Teleostei posiada łuski elastyczne dwojakiego rodzaju: okragławe (cykloidalne) i zgrzebłowate (ktenoidalne). Łuski cykloidalne maja gładkie brzegi (Ryc. 3E), podczas gdy łuski ktenoidalne wyróżniają się obecnościa drobnych zabków osadzonych na tylnym brzegu łuski (Ryc. 3F) i występuja u bardziej zaawansowanych Teleostei $z$ grupy ryb kolcopłetwych (Acanthopterygii) (WAINWRIGHT i LAUDER 2017). U niektórych ryb łuski moga ulegać redukcji, jak np. u węgorzy, natomiast ryby $z$ rodziny flacdrowatych posiadaja zarówno łuski cykloidalne, jak i ktenoidalne. Oprócz tych dwóch typów łusek elastycznych, u niektórych Teleostei występuja także łuski kolczaste (ang. spinoid) i karbowane (ang. crenate) o falistej powierzchni (WAINWRIGHT i LAUDER 2017). W rzeczywistości różnorodność łusek i ukształtowania ich powierzchni jest duża, a w związku $z$ tym niejednokrotnie trudne jest zaklasyfikowanie konkretnej łuski do jednego ze wspomnianych typów.

U miękławki, latimerii i ryb dwudysznych łuski elastyczne sa wyjątkowe pod względem ułożenia zgrubieni. Nie tworza one 
koncentrycznych pierścieni jak u Teleostei, a raczej zgrubienia ułożone promieniście (łuski radialne).

\section{PANCERZE U TELEOSTEI}

W niektórych liniach ewolucyjnych ryb ewolucja nie szła w kierunku wykształcenia cienkich, elastycznych łusek, a wręcz przeciwnie, powstały grubsze elementy kostne stanowiące silne wzmocnienie pokrycia ciała. Pierwotnie łuski ganoidalne tworzyły właśnie taki pancerz u pierwotnych kostnoszkieletowych, a wśród współczesnych u wielopłetwców (Polypterus) i niszczuk (Lepisosteus). U jesiotrów (Acipenser) płytki kostne tworza jedynie pięć pasów ułożonych wzdłuż ciała. Natomiast u niektórych Teleostei doszło do wytworzenia kostnego pancerza skórnego de novo. U sumików pancernych (ang. armoured catfishes), do których zalicza się trzy rodziny $z$ rzędu sumokształtnych (Siluriformes): kirysowate (Doradidae), kiryskowate (Callichthyidae), zbrojnikowate (Loricariidae), występuja tarczki kostne (ang. scutes) zbudowane $z$ grubej warstwy kości pokrytej wcześniej wspomniana hialoina (ang. hyaloine), a na tylnym końcu tarczki znajduje się pokryty szkliwem ząbek zbudowany $z$ zębiny (Ryc. 3G) (SIRE 1993, SiRE i współaut. 2009). Natomiast płytki kostne (ang. dermal plates), zbudowane jedynie $z$ kości położonej w skórze właściwej, pokrywaja ciało ryb z rzędów ciernikokształtnych (Gasterosteiformes), rozdymkokształtnych (Tetraodontiformes) i igliczniokształtnych (Syngnathiformes) (Ryc. 3H) (SIRE 1993, SiRE i współaut. 2009). Tarczki i płytki kostne sa inaczej zbudowane i powstały $\mathrm{w}$ ewolucji niezależnie, dlatego dla ich nazwania wykorzystano dwa różne terminy. Ponadto uznaje się, że tarczki i plytki kostne ryb Teleostei nie sa przekształconymi łuskami, gdyż powstaja w rozwoju $z$ innych linii komórkowych, mianowicie $z$ komórek kościotwórczych (osteoblastów), które różnicują się w głębokich warstwach skóry właściwej. Natomiast osteoblasty nie uczestnicza w rozwoju łusek elastycznych, gdyż łuski te nie zawierają elementów tkanki kostnej.

\section{ŁUSKI KOSMOIDALNE}

U wczesnych ryb $z$ gromady mięśniopłetwych (Sarcopterygii), w dewonie (ok. 405 $\mathrm{mln}$ lat temu) powstały łuski posiadajace wyjątkowy układ pionowych i poziomych kanałów, łączących się $z$ butelkowatymi przestrzeniami uchodzacymi na powierzchnię luski za pomoca porów (ang. pore-canal network) (Ryc. 4A) (BORGEN 1989, BEMIS i NORTHCUTT 1992, SIRE i współaut. 2009). Kanały i przestrzenie znajdowały się $\mathrm{w}$ obrębie zębiny (ortodentyna) i były wysłane szkliwem

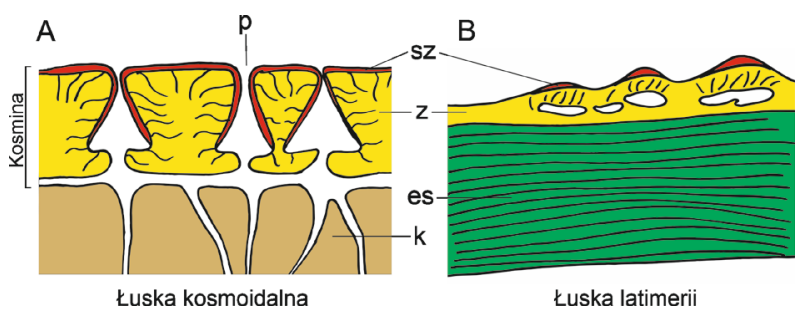

Ryc. 4. Łuski ryb mięśniopłetwych (Sarcopterygii). A. Łuska kosmoidalna kopalnych ryb mięśniopłetwych zbudowana jest $\mathrm{z}$ tkanki kostnej $(\mathrm{k})$ pokrytej kosmina stanowiaca system kanałów i przestrzeni w zębinie (z) i szkliwie (sz), uchodzacych na powierzchnię łuski przez pory (p). B. Łuska latimerii zbudowana jest $z$ warstwy elasmodyny (es), a na powierzchni jej tylnej części znajduja się zredukowane pozostałości zębiny (z) i szkliwa (sz).

prawdziwym. Taki układ kanałów, przestrzeni i porów obejmujacy zębinę i szkliwo nazwano kosmina. Jest ona synapomorfia ryb $z$ gromady Sarcopterygii, ale nie występuje $\mathrm{u}$ żadnych ze współczesnych ryb (SCHULTZE 2016). Nie wiadomo, jaka pełniła funkcję. Wśród współczesnych ryb dwudysznych występuja butelkowate narządy zmysłów na powierzchni ciała, co wskazuje, że specyficzna budowa kosminy mogła mieć zwiazek z odbieraniem bodźców. Łuski kosmoidalne były podobne do łusek ganoidalnych pod względem kolejności ułożenia warstw (szkliwo, ortodentyna, izopedyna).

W linii ewolucyjnej prowadzacej do latimerii (celakantokształtne, Coelacanthiformes, Actinistia) kosmina ulegała stopniowej redukcji, podobnie jak izopedyna tworzaca podstawę łuski. W efekcie powstała łuska współczesnej latimerii (Latimeria chalumnae) zbudowana $z$ niezmineralizowanej elasmodyny, w tylnej części pokrytej resztką zębiny i szkliwa (Ryc. 4B) (MEUNIER 1980).

U pierwotnych dewońskich przedstawicieli grupy Dipnomorpha (linia prowadzaca do współczesnych ryb dwudysznych, Dipnoi), takich jak Porolepis, występowała kosmina, ze szkliwem pokrywajacym także przestrzenie wewnątrz kosminy, która w późniejszych grupach (po dewonie) uległa zanikowi (SIRE i współaut. 2009). Współczesne ryby dwudyszne maja cienkie łuski elastyczne zbudowane $z$ dobrze zmineralizowanej tkanki (MEUNIER 1983).

\section{ROZWÓJ ŁUSEK}

W zawiąku łuski wyróżnia się dwie części: część osteogeniczna, czyli kościotwórczą, położona w głębszych warstwach skóry, oraz 
część odontogeniczną, czyli zębinotwórczą, położoną bliżej naskórka (SIRE i HUYSSEUNE 2003).

Pierwszym przejawem rozpoczęcia tworzenia się łuski jest zgrubienie nabłonka, pod którym zaczynają skupiać się komórki mezenchymatyczne, tworzac brodawkę skórna (SIRE i HuYsSEUne 2003). Rozrastajaca się brodawka uwypukla się w kierunku powierzchni skóry. Komórki mezenchymy pochodzą $z$ grzebieni nerwowych i różnicuja się w odontoblasty, które zaczynaja odkładać zębinę w kierunku nabłonka (ku powierzchni). Początkowo odontoblasty odsuwaja się od błony podstawnej, która leży u podstawy nabłonka, pozostaja jednak połaczone $z$ nia wypustkami. Przestrzeń pomiędzy odontoblastami a błona podstawna wypełnia się kolagenem (predentyna) produkowanym przez te komórki, a w dalszej kolejności warstwa ta ulega mineralizacji tworzacc dentynę (zębinę). Komórki nabłonka (a więc komórki położone po przeciwnej stronie błony podstawnej) różnicują w ameloblasty i zaczynają odkładać szkliwo w kierunku zębiny. W bardzo podobny sposób zaczynają rozwijać się zęby, $z$ tą różnica, że zawiązek zęba wpukla się w głąb tkanki łącznej.

Różnorodność struktury łusek poszczególnych grup ryb znajduje odzwierciedlenie $\mathrm{w}$ toku ich rozwoju. W rozwoju łuski plakoidalnej ryb chrzęstnoszkieletowych, odontoblasty w pierwszej kolejności zaczynaja produkować enameloid - warstwę substancji międzykomórkowej, głównie kolagenu, która ulega mineralizacji (SIRE i HUYSSEUNE 2003). Nastepnie zanika błona podstawna oddzielajaca nabłonek od skóry właściwej, a ameloblasty utworzone $\mathrm{w}$ nabłonku uczestnicza w mineralizacji enameloidu. Odontoblasty zaczynaja produkować kolejna porcje substancji międzykomórkowej, która ulega mineralizacji. Tym razem utworzy ona zębinę. W głębszych warstwach skóry właściwej różnicuja się osteoblasty tworzace płytkę kostna. W efekcie powstaje łuska zbudowana $z$ zębiny pokrytej enameloidem, osadzona na kostnej płytce (SIRE i HUYSSEUNE 2003).

Wielu kluczowych informacji na temat pochodzenia poszczególnych warstw łuski dostarczyły badania nad rozwojem łuski wielopłetwca (Polypterus), która najbardziej przypomina pierwotne łuski ryb kostnoszkieletowych (SIRE 1989, 1995, SIRE i współaut. 1987, SiRE i HUYSSEUNE 2003). W rozwoju łusek Polypterus najsilniej rozwinięta jest część odontogeniczna. Odontoblasty zaczynaja odkładać zębinę w kierunku nabłonka. Komórki nabłonkowe najgłębszych warstw naskórka różnicują się w ameloblasty i zaczynają produkować ganoinę w głąb skóry, a więc w kierunku tworzącej się zębiny. Poni- żej $\mathrm{z}$ odontoblastów różnicują się elasmoblasty, które produkują elasmodynę. Rozrastający się zawiazek łusek wchodzi w kontakt $z$ naczyniami krwionośnymi głębszych warstw skóry właściwej. Wokół naczyń krwionośnych różnicują się komórki osteogeniczne (osteoblasty) tworzace tkanke kostną, która utworzy kostna płytkę podstawną łuski.

W rozwoju łuski Lepisosteus nie różnicuja się odontoblasty, w związku z tym nie tworzy się zębina (SIRE 1994, 1995). Główną rolę w rozwoju łusek tych ryb odgrywa część osteogeniczna. W pierwszej fazie rozwoju łuski różnicuja się tu komórki osteogeniczne tworzące płytkę kostną w skórze właściwej, która rozrasta się w kierunku nabłonka. W nabłonku różnicuja się ameloblasty tworzące ganoinę. W końcu płytka kostna, zbudowana $z$ izopedyny, zespala się $z$ ganoina.

W rozwoju łuski elastycznej nie powstaje zgrubienie nabłonka (SIRE i HuYSSEUNE 2003). Pod błona podstawna skupiaja się komórki mezenchymatyczne, które tworza dwie warstwy elasmoblastów (SIRE i AKIMENKO 2004). Komórki górnej warstwy zaczynaja produkować płytkę zbudowana $z$ kolagenu, która szybko ulega wysyceniu substancja mineralna. Aktywność górnej warstwy elasmoblastów zanika, a w tym czasie dolne warstwy elasmoblastów dobudowuja elasmodynę, w postaci kolejnych warstw powoli mineralizującego kolagenu (SIRE i HUYSSEU$\mathrm{NE}$ 2003). Elasmoblasty powstaja $z$ brodawki odontogenicznej, co wskazuje, że elasmodyna prawdopodobnie jest forma zębiny, a nie izopedyna, jak wcześniej uważano. Na górnej powierzchni łuski, pokrytej nabłonkiem, okresowo odkładana jest warstwa graniczna. Przypuszczalnie materiał ten zawiera substancje pochodzace $z$ nabłonka (SIRE i HUYSSEUNE 2003).

Molekularne mechanizmy kierujace rozwojem łusek ryb sa słabo poznane. Wiadomo, że gen sonic hedgehog (shh) ulega ekspresji w nabłonku ponad powstajacymi łuskami danio pregowanego (Danio rerio) i być może stanowi sygnał dla różnicowania się komórek mezenchymalnych w rozwoju łusek (SIRE i AKIMENKO 2004). Dodatkowo w kontroli rozwoju łusek u danio biora udział czynniki sygnalizacyjne WNT, ektodysplazyna (EDA) i fibroblastyczne czynniki wzrostu (FGF) (AMAN i współaut. 2018).

\section{PODSUMOWANIE}

Ogólny plan budowy łuski powstał już u wczesnych, paleozoicznych bezszczękowców, u których wytworzyła się specyficzna tkanka - zębina. Analiza rozwoju i budowy łusek w poszczególnych grupach ryb ujawnia hipotetyczny przebieg ewolucji łusek. Pierwotne 
łuski powstawały $z$ dwóch części: (i) osteogenicznej, tworzacej kostna płytkę u podstawy łusek oraz (ii) odontogenicznej, tworzącej zębinę i szkliwo. W efekcie powstawała gruba łuska, obecna m.in. u pierwotnych ryb kostnoszkieletowych i u współczesnego Polypterus. W linii ewolucyjnej jesiotrokształtnych (Acipenseriformes) i niszczukokształtnych (Lepisosteiformes) doszło do redukcji części odontogenicznej, w wyniku czego łuski tych ryb sa zbudowane wyłącznie, lub w znaczącej części, z tkanki kostnej. Natomiast w linii ewolucyjnej Amiiformes i Teleostei, zanikowi uległa część osteogeniczna, a tym samym wyeliminowana została $z$ łuski tkanka kostna. W niektórych liniach ewolucyjnych Teleostei, takich jak sumiki pancerne i ciernikowate, doszło do zaniku łusek elastycznych oraz do powstania de novo struktur kostnych w postaci tarczek i płytek, co zapewne było wynikiem zaniku części odonotogenicznej i ponownego wyodrębnienia się części osteogenicznej. Przypuszczalnie, w najwcześniejszych etapach rozwoju każdej łuski gromadza się komórki mezenchymalne, które ulegają wpływom różnych czynników wzrostu, które $z$ kolei indukują wchodzenie tych komórek na drogę różnicowania się w odontoblasty syntetyzujace zębinę, bądź w osteoblasty, tworzace tkankę kostną. Tak więc komórki o tym samym pochodzeniu poddane wpływom różnych czynników wzrostu tworza odmienne struktury, a zmiany w ekspresji owych czynników prawdopodobnie odpowiadały za zmiany w strukturze łusek podczas ich ewolucji.

\section{Streszczenie}

Skóra wielu kręgowców tworzy struktury wzmacniające jej ochronę. Już paleozoiczne bezszczękowce były pokryte różnorodnymi łuskami lub pancerzami. Jednym ze składników tych struktur jest zębina, na powierzchni której odkładana była silnie zmineralizowana tkanka, tak zwany enameloid, a więc tkanka szkliwo-podobna. Zębina osadzona jest na kostnej podstawie. U współczesnych ryb chrzęstnoszkieletowych występuja łuski plakoidalne, mające postać ząbków zbudowanych $z$ zębiny pokrytej enameloidem i osadzonej na kostnej płytce. U wczesnych ryb kostnoszkieletowych po raz pierwszy powstało szkliwo. Najbardziej pierwotną łuskę wśród współczesnych ryb kostnoszkieletowych posiada wielopłetwiec. Jego łuska jest łuską ganoidalna, pokryta wielowarstwowym szkliwem, zwanym ganoina. Pod ganoina znajduje się zębina, a pod nią elasmodyna i warstwa kości. W toku ewolucji tak grube łuski ulegały przekształceniu w cienkie łuski elastyczne, które występuja m. in. u ryb doskonałokostnych. U kopalnych ryb mięśniopłetwych wystepowały łuski kosmoidalne pokryte kosmina, bedaca systemem kanałów i porów w obrębie zębiny i szkliwa.

\section{LITERATURA}

Aman A. J., Fulbright A. N., PARIChy D. M., 2018. Wnt/ $\beta$-catenin regulates an ancient si- gnaling network during zebrafish scale development. eLife 7, e37001.

Bemis W. E., NORTHCUTT R. G., 1992. Skin and blood vessels of the snout of the Australian lungfish, Neoceratodus forsteri, and their significance for interpreting the cosmine of Devonian lungfishes. Acta Zool. (Stockh.) 73, 115139.

BORGEN U. J., 1989. Cosmine resorption structures on three osteolepid jaws and their biological significance. Lethaia 22, 413-424.

BuRROW C. J., TURNER S., 1999. A review of placoderm scales, and their significance in placoderm phylogeny. J. Vertebr. Paleontol. 19, 204-219.

BurRow C. J., TrinaJsTiC K., LONG J., 2012. First acanthodian from the Upper Devonian (Frasnian) Gogo Formation, Western Australia. Hist. Biol. 24, 349-357.

DAVIT-BÉAL T., ÁLLIZARD F., SIRE J. Y., 2007. Enameloid/enamel transition through successive tooth replacements in Pleurodeles waltl (Lissamphibia, Caudata). Cell Tissue Res. 328, 167-183.

DENison R. H., 1978. Placodermi. Gustav Fisher, Stuttgart.

Donoghue P. C. J., AldRidge R. J., 2001. Origin of a mineralised skeleton. [W:] Major Events in Early Vertebrate Evolution: Palaeontology, Phylogeny, Genetics and Development. AHLBERG P. E. (red.). Taylor \& Francis, London, 85-105.

Donoghue P. C. J., SANSOM I. J., 2002. Origin and early evolution of vertebrate skeletonization. Microsc. Res. Techn. 59, 185-218.

Donoghue P. C. J., SANSOM I. J., Downs J. P., 2006. Early evolution of verte-brate skeletal tissues and cellular interactions, and the canalization ofskeletal development. J. Exp. Zool. 306B, 278-294.

FRIEDMAN M., BRAZEAU M. D., 2010. A reappraisal of the origin and basalradiation of the Osteichthyes. J. Vertebr. Paleontol. 30, 36-56.

GrodZIŃSKI Z., 1978. Pokrycie ciała. [W:] SZARSKI H. (red.). Anatomia porównawcza kręgowców. PWN, Warszawa, 43-90.

JANVIER P., ARSENAUlT M., 2007. The anatomy of Euphanerops longaevus Woodward, 1900, an anaspid-like jawless vertebrate from the Upper Devonian of Miguasha, Quebec, Canada. Geodiversitas 29, 143-216.

Janvier P., Thanh T. D., Phuong T. H., 1993. A new early Devonian galeaspid from Bac Thai Province, Vietnam. Palaeontology 36, 297-309.

Karatajuté-TAlimaA V., SMith M. M., 2003. Early acanthodians from the Lower Silurian of Asia. Trans. R. Soc. Edinb. (Earth Sci.) 93, $277-$ 299.

MÄRSS T., 2001. Andreolepis (Actinopterygii) in the Upper Silurian of northern Eurasia. Proc. Est. Acad. Sci., Geol. 50, 174-189.

MEUNIER F. J., 1980. Les relations isopédine-tissu osseux dans le posttemporal et les écailles de la ligne latérale de Latimeria chalumnae (Smith). Zool. Scr. 9, 307-317.

MEUNIER F. J., 1981. 'Twisted plywood' structure and mineralization in the scales of a primitive living fish, Amia calva. Tissue Cell 13, 165171 .

MEUNIER F. J., 1983. Les tissus osseux des Ostéichthyens Structure, genèse, croissance et évolution. Université Paris 7, Thèse de Doctorat ès Sciences.

Miyake T., Vaglia J. L., Taylor L. H., Hall B. K., 1999. Development of dermal denticles in skates (Chondrichthyes, Batoidea): patterning 
and cellular differentiation. J. Morphol. 241, 61-81.

NANCI A., 2003. Enamel: Composition, formation and structure. [W:] Ten Cate's Oral Histology: Development, Structure, and Function. NANCI A. (red.). Harcourt Health Sciences, St. Louis, 145-191.

ØRVIG T., 1967. Phylogeny of tooth tissues: evolution of some calcified tissues in early vertebrates. [W:] Structural and Chemical Organisation of Teeth. Miles A. E. W. (red.). Academic Press, New York, 45-110.

Osborn J. W., 1981. Dental Anatomy and Embryology. Blackwell Scientific Publications, London.

Qu Q., Haitina T., Zhu M., AhlBerg P. E., 2015. New genomic and fossil data illuminate the origin of enamel. Nature 526, 108-111.

REIF W. E., 1982. Evolution of dermal skeleton and dentition in vertebrates. The odontode regulation theory. Evol. Biol. 15, 278-386.

SAnsom I. J., SMith M. P., SMiTh M. M., 1996. Scales of thelodont and shark-like fishes from the Ordovician. Nature 379, 628-630.

Schultze H. P., 2016. Scales, Enamel, Cosmine, Ganoine, and Early Osteichthyans. C. R. Palevol 15, 83-102.

SHU D. G., CONWAY MORRIS S., HAN J., ZHANG Z. F., YASUI K., JANVIER P., CHen L., ZHANG X. L., LIU J. N., LI Y., LIU H. Q., 2003. Head and backbone of the Early Cambrian vertebrate Haikouichthys. Nature 421, 526-529.

SiRE J. Y., 1989. The scales in young Polypterus senegalus are elasmoid: new phylogenetic implications. Am. J. Anat. 186, 315-323.

SIRE J. Y., 1993. Development and fine structure of the bony scutes in Corydoras arcuatus (Siluriformes, Callichthyidae). J. Morphol. 215, $225-244$.

SIRE J. Y., 1994. A light and TEM study of non-regenerated and experimentally regenerated scales of Lepisosteus oculatus (Holostei) with particular attention to ganoine formation. Anat. Rec. 240, 189-207.

SIRE J. Y., 1995. Ganoine formation in the scales of primitive actinopterygian fishes, lepisosteids and polypterids. Connect. Tissue Res. 32, 535-544.

SIRE J. Y., HuYSSEUNE A., 2003. Formation of dermal skeletal and dental tissues in fish: a comparative and evolutionary approach. Biol. Rev. 78, 219-249.

SiRE J. Y., AKIMENKo M. A., 2004. Scale development in fish: a review, with description of sonic hedgehog (shh) expression in the zebrafish (Danio rerio). Int. J. Dev. Biol. 48, 233247.

SIRE J. Y., KAWASAKI K., 2012. Origin and evolution of bone and dentin and of acidic secretory calcium-binding phosphoproteins. [W:] Phosphorylated Extracellular Matrix Proteins of Bone and Dentin. GOLDBERG M. (red.). Bentham Science Publishers, 3-60.

SiRE J. Y., GÉRAUDIE J., MEUNIER F. J., ZYLBERBERG L., 1987. On the origin of ganoine: histological and ultrastructural data on the experimental regeneration of the scales of Calamoichthys calabaricus (Osteichthyes, Brachyopterygii, Polypteridae). Am. J. Anat. 180, 391-402.

Sire J. Y., Donoghue P. C., Vickaryous M. K., 2009. Origin and evolution of the integumentary skeleton in non-tetrapod vertebrates. J. Anat. 214, 409-440.

WAINWRIGHT D. K., LAUDER G. V., 2017. Mucus matters: the slippery and complex surfaces of fish. [W:] Functional Surfaces in Biology III. GORB S., GORB E. (red.). Springer, Cham, 223-246.

ZHU M., YU X., 2002. A primitive fish close to the common ancestor of tetrapods and lungfish. Nature 418, 767-770.

KOSMOS Vol. 70, 4, 625-635, 2021

RAFAE P. PIPREK

Department of Comparative Anatomy, Institute of Zoology and Biomedical Research, Jagiellonian University, 9 Gronostajowa Str., 30387 Kraków, E-mail: rafal.piprek@uj.edu.pl

NATURAL HISTORY OF FISH SCALES - STRUCTURE, EVOLUTION AND DEVELOPMENT

\section{Summary}

The skin of many vertebrates forms structures, such as fish scales, that strengthen its protection. Palaeozoic jawless fishes were covered with a variety of scales or armor. One of the components of these structures is dentin. A strongly mineralized tissue, the enameloid, i.e. enamel-like tissue, is deposited on the dentin surface. The dentin is based on the bony plate. In modern cartilaginous fishes there are placoid scales in the form of teeth formed by dentine covered with enameloid, based on a bone plate. For the first time enamel appeared in the early bonny fishes. The modern Polypterus has the most primitive scales among bonny fishes. Its scale is of the ganoid type and is covered with a multi-layered enamel called ganoin. Underneath ganoin dentin is located and there is a bone plate at the base of the scales. In the course of evolution, such thick scales were transformed into thin elastic scales that occur among teleost fishes. The fossil sarcopterygian fishes had cosmoid scales covered with cosmin, which is a system of channels and pores within the dentin and enamel. 